\title{
Effect of Financial Statements Quality on Information Asymmetry and Investment Efficiency as Moderating Variable in Mining Companies
}

\author{
Ida Ayu Agung Emawati* I Gusti Ayu Nyoman Budiasih \\ Faculty of Economics and Business, University of Udayana, Denpasar, Indonesia
}

\begin{abstract}
Efficiency investments made by the internal company is expected to improve the financial statements reporting by the company better than reducing the information asymmetri between internal company and investors. The purpose of this study are determine the effect on the quality of financial statements with information asymmetry and use investment efficiency as a moderating variable. This study uses mining companies that listed on the Indonesia Stock Exchange in 2013-2015. Samples were obtained by 84 companies with nonprobability sampling methods with purposive sampling. Data analysis technique conducted is moderated regression analysis. The result finds that quality of financial reporting has negative effect on information asymmetry. Efficiency investments strengthen the negative effect on the quality of reporting of information asymmetry.
\end{abstract}

Keywords: investment efficiency, quality of financial reports, information asymmetry

DOI: $10.7176 /$ RJFA/11-8-03

Publication date: April $30^{\text {th }} 2020$

\section{Introduction}

The capital market is a place for investors to invest their capital as well as to facilitate investment activities they do which have an important role for the country's progress. Investment is an activity to allocate funds owned by individuals or organizations within a certain period in order to obtain a return or return from the amount of funds that have been allocated (Ivan, 2013). The investment process certainly requires analysis and in-depth calculations with due regard to the principle of caution. In general, investors will be braver and feel safer to invest in companies that have relatively high profits. This is because companies with relatively high profits are suspected of having good prospects in the future and allowing investors to obtain large returns.

The business sector which is generally attractive to investors as its investment target, is the mining sector. Unstable economic power, fears of the dangers of pollution to the environment, as well as competition with the use of cleaner fuels are now making countries in the world slowly move away from coal which was once successful in driving the Indonesian industrial revolution in the mining sector. In 2012, the government issued Ministerial Regulation (Permen) Number 11 of 2012 concerning Amendments to Ministerial Regulation (Permen) Number 7 of 2012 which states that all mining businesses in the mineral sector are required to process and refine domestic mining products and are prohibited from exporting mining materials. raw (www.esdm.go.id). After the enactment of the regulation, the mining industry in Indonesia experienced a decline in income. This can be proven in Graph 1 which shows that from 2012 to 2015 , the contribution of income in the mining sector has continued to decline.

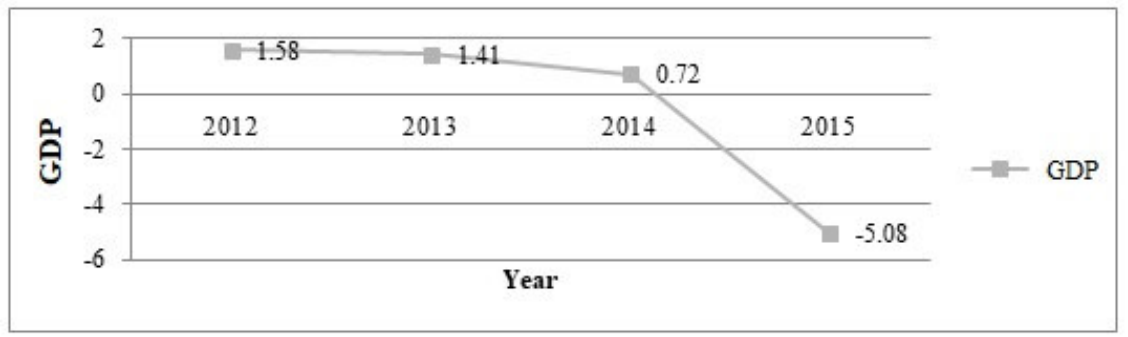

Figure 1. 2012-2015 Mining Sector GDP Growth Rate

Revenue contribution in the mining sector is continuously decreasing when compared to other business sectors. The mining sector contributed the lowest income in 2015 as evidenced by the 2015 Central Statistics Agency data in Table 1. 
Table 1. Indonesia's GDP Growth Rate in 2015

\begin{tabular}{|c|l|c|}
\hline No & \multicolumn{1}{|c|}{ Business Field } & $\begin{array}{c}\text { GDP growth rate in } \\
\mathbf{2 0 1 5} \\
\text { ( persen) }\end{array}$ \\
\hline 1 & Agriculture, Animal Husbandry, Forestry, and Fisheries & 4,02 \\
\hline 2 & Mining and excavation & $-5,08$ \\
\hline 3 & Processing industry & 4,25 \\
\hline 4 & Electricity, Gas and Clean Water & 1,21 \\
\hline 5 & Construction & 6,65 \\
\hline 6 & Trade, Hotels and Restaurants & 2,47 \\
\hline 7 & Transportation and Communication & 10,06 \\
\hline 8 & Finance, Real Estate, and Corporate Services & 5,92 \\
\hline 9 & Services & 8,08 \\
\hline \multicolumn{2}{|c|}{ Gross Domestic Product (GDP) of 2015 } & 4,79 \\
\hline
\end{tabular}

The low revenue contribution generated by mining sector companies can have an impact on investment activities that will be carried out by investors in these mining sector companies. Investors allegedly will not be interested and are not interested in investing because it is likely not to provide large profits or returns for investors, where investors are only interested in investing in companies that tend to generate large returns because investors invest in companies with returns that are then the investor will be able to obtain a large profit as well.

The motivation in this study is to examine how the quality of financial statements affects information asymmetry with investment efficiency as a moderating variable in mining sector companies on the Indonesia Stock Exchange with the 2013-2015 observation year due to a phenomenon that occurred in 2012, namely the enactment of Ministerial Regulation No . 11 of 2012 which caused a decrease in revenue contribution from 2013 to 2015 in the mining sector. This will certainly affect the efficiency of investment by companies by looking at how the quality of financial statements and their influence on information asymmetry.

The formulation of the problem of this research is how the influence of the quality of financial statements on information asymmetry and how the ability of investment efficiency moderate the influence of the quality of financial statements on information asymmetry. The research objective is to obtain empirical evidence of the negative influence of the quality of financial statements on information asymmetry and to get empirical evidence of the ability of investment efficiency to moderate the effect of the quality of financial statements on information asymmetry.

\section{Theory Review and Hypothesis Development}

\subsection{Agency Theory}

Agency theory is a contract in which the principal gives authority in making decisions to the agent to carry out a number of jobs on behalf of the principal (Jensen \& Meckling, 1976). The main principle of agency theory is the existence of an employment relationship in the form of a cooperation contract between the principal and the agent, referred to as the "nexus of contract". If the principal and the agent involved in the cooperation contract try to obtain their respective interests to the maximum, then there will be a tendency for the agent to not always act in the best interests of the principal.

\subsection{Investment Efficiency}

Investment is an activity carried out by the company in an effort to develop and increase the value of the company. Investment activities should be carried out efficiently in order to achieve the expected level of profit. Investment efficiency is the optimal level of investment that is able to provide benefits to the company (Sari \& Suaryana, 2014). There are two factors that can determine investment efficiency. First, companies are deemed necessary to increase business capital to finance investment opportunities. Second, if the company makes an investment decision that is believed to increase capital but there is no certainty that the investment is in accordance with the needs, then an appropriate investment decision is needed (Sari \& Suaryana, 2014). Investment decisions to be made by a company should be made based on accounting information circulating on the exchange. The financial statements presented by the company must reflect the financial position and the actual condition of the company so that the company is able to carry out investment activities optimally and does not experience underinvestment or overinvestment conditions.

\subsection{Information Asymmetry}

Asymmetry of information is a condition regarding information in the company's financial statements reported by the company management does not reflect the actual condition of the company. A high quality company financial report is able to minimize the emergence of information asymmetry between company management and investors 
(Verdi, 2006). The high quality of financial statements can cause investment decisions taken by companies to be more optimal and can improve the monitoring function in overseeing the activities of company management.

\subsection{Quality of Financial Reports}

An important component that is important to consider for a company is the quality of the company's financial statements. Financial statements can be said to be quality if they have presented the actual condition of the company. The high quality of a financial statement can minimize information asymmetry, adverse selection, and moral hazard, and can cause companies to be able to identify a variety of investment opportunities better. According to Gomariz \& Ballesta (2013), the high quality of financial statements can enable better supervision or monitoring of shareholders so that company management becomes more responsible in presenting a financial statement.

\subsection{Hypothesis Development}

\subsubsection{The Effect of the Quality of Financial Statements on Information Asymmetry}

The presentation of quality financial information is expected to reduce information asymmetry between company management and investors (Cohen, 2003). Research by Setiany \& Wulandari (2015) also found the same results, namely the quality of financial statements has a negative influence on information asymmetry. This means that the high quality of a financial statement can reduce the level of information asymmetry between company management and investors. Research by Fanani (2009) also shows the same results, namely the presentation of higher quality financial statements can reduce information asymmetry. According to Amrullah \& Fatima (2015), the high quality of a company's financial statements can minimize the emergence of information asymmetry so that investment activities carried out by investors reach optimal levels. However, it is different from the results of Indriani \& Khoiriyah's research (2010) which shows that the quality of financial statements represented by the relevance of values, timeliness, and conservatism has a positive influence on information asymmetry. The results of Kusuma et al. (2014) and Santoso (2012) also show that the quality of financial statements does not have a significant effect on information asymmetry. The first hypothesis of this research is:

$\mathrm{H}_{1}$ : The quality of financial statements has a negative effect on information asymmetry.

\subsubsection{Investment Efficiency Strengthens the Effect of Financial Statement Quality on Information Asymmetry}

Quality financial statements that can reduce the level of information asymmetry between company management and investors because the financial statements that are presented in a quality manner have described how the company's actual condition so that there is no difference in the acquisition of information between company management and investors. The low information asymmetry with the presentation of higher quality financial statements can result in investments made by investors to be more optimal and able to obtain the returns that investors want. According to Tao Ma (2012), a company should pay attention to the high quality of a financial statement with a low level of information asymmetry so as to facilitate investment activities to be carried out by investors. This statement is in line with the results of Bushman \& Smith's research (2003) which explains that quality financial reports directly make company management more accountable so that it can reduce information asymmetry and reduce the level of moral hazard in determining investment opportunities.

Investments made efficiently by the company's internal parties can strengthen the effect of the financial statements that are presented to be of higher quality in the low information asymmetry between company management and investors. According to Butar (2015), financial statements have an important role in reducing investment inefficiency that comes from underinvestment and overinvestment conditions. The efficiency of investments made by internal companies in developing the value of a company's investment can affect the quality of financial statements in presenting accounting information for a company. The presentation of quality company financial statements by internal parties of the company will affect the level of information asymmetry that is getting lower between the company's internal parties and investors as seen from the level of spread. The second hypothesis of this study is:

$\mathrm{H}_{2}$ : Investment efficiency strengthens the effect of financial statement quality on information asymmetry.

\section{Research Methods}

This research uses a quantitative approach in the form of associative. The research locations are mining sector companies in the Indonesia Stock Exchange for the period 2013-2015 through the official website www.idx.co.id. The object of research is investment efficiency as a moderating effect of the quality of financial statements on information asymmetry. The type of data is quantitative data. The data source is secondary data. The study uses investment efficiency as a moderating variable, the quality of financial statements as an independent variable, information asymmetry as the dependent variable. 


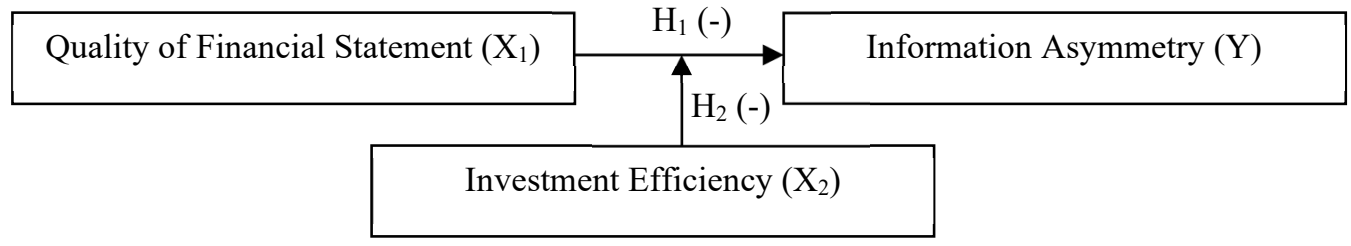

Figure 2. Research Conceptual Framework

This study uses 3 (three) years of research, namely 2013, 2014 and 2015. This is due to a phenomenon regarding the issuance of Ministerial Regulation No. 11 of 2012 which resulted in the contribution of mining sector revenue has decreased continuously after the enactment of the regulation, namely 2013 to 2015 so that it will also have an impact on the efficiency of investment to be made in the mining company. The research population is all companies in the mining sector on the Indonesia Stock Exchange in 2013 to 2015, which is a number of 41 companies. The process of determining the sample is the nonprobability sampling method using purposive sampling technique so that 84 samples are obtained using three years of observation.

As for the criteria in sample selection, the first criterion is mining companies that publish audited annual financial statements in 2013-2015. This is because the audited financial statements of a company have been examined by an independent auditor, namely a third party outside the company that is independent so that it is able to present all information about the company's performance in a relevant and reliable manner. The second criterion is mining companies which in full annual financial statements present the information needed to calculate the research variables.

Based on Table 2, the total population of the study is 123 companies, but there are 33 companies that do not publish audited annual financial statements in 2013-2015 and 6 companies in their financial statements present incomplete information for calculating research variables. Thus, the number of research samples for three years of observation is 84 .

Table 2. Research Sample Determination Process

\begin{tabular}{lc}
\hline \multicolumn{1}{c}{ Criteria } & Number of Companies \\
\hline Research population & 123 \\
$1 \quad \begin{array}{l}\text { Mining companies that do not publish audited } \\
\text { annual financial statements for the 2013-2015 }\end{array}$ & $(33)$ \\
$\begin{array}{l}\text { period. } \\
2 \quad \begin{array}{l}\text { Mining companies which have incomplete } \\
\text { financial statements present information to } \\
\text { calculate research variables. }\end{array}\end{array}$ \\
\hline Total research sample with three years of observation \\
\hline Total sample of companies studied & $(6)$ \\
\hline
\end{tabular}

Data collection method is nonparticipant observation method. The data analysis technique of this research is Moderated Regression Analysis (MRA) which is processed with the SPSS program. The equation model of moderated regression analysis used in the study are:

Information:

$$
\mathrm{Y}=\beta_{0}+\beta_{1} \mathrm{X}_{1}+\beta_{1} \mathrm{X}_{2}+\beta_{3} \mathrm{X}_{1} \mathrm{X}_{2}+\mathrm{e}
$$

Y : Information Asymmetry

$\beta_{0} \quad$ : A constant

$\beta_{(1,2,3)} \quad$ : Regression coefficient

$\beta_{3} \quad:$ Interaction Coefficient

$\mathrm{X}_{1} \quad$ : Quality of financial statements

$\mathrm{X}_{2} \quad$ : Investment efficiency

$\mathrm{X}_{1} \mathrm{X}_{2} \quad$ : Interaction between the quality of financial statements with investment efficiency

e : Standard error

Measurement of investment efficiency variables uses investment models that function as growth opportunities or company growth opportunities (Biddle et al., 2009). The investment model is as follows:

Information:

Investment $_{\mathrm{i}, \mathrm{t}+1}=\beta_{0}+\beta_{1} *$ Sales Growth $\mathrm{i}_{\mathrm{i}, \mathrm{t}}+\mathrm{e}_{\mathrm{i}, \mathrm{t}+1}$

Investment $\mathrm{i}_{\mathrm{t}, \mathrm{1}} \quad$ : The total investment in fixed assets

Sales Growth ${ }_{\mathrm{i}, \mathrm{t}} \quad$ : Percentage of change in the company's current sales value with the previous year

Investment efficiency which is proxied using the investment model will later obtain a residual value which is used as a measurement of investment efficiency variables.

The quality of financial statements can be proxied by the quality of accruals (Biddle \& Hilary, 2006). This 
study follows the accrual measurement model by Kothari et al. (2005) to be able to measure total accruals. The higher total accruals indicate that the lower the quality of the financial statements presented by a company. Conversely, the lower the total accruals indicate that the higher the quality of the financial statements presented by a company. The accrual calculation model for measuring the variable quality of financial statements by Kothari et al. (2005) are as follows:

Information:

$$
\mathrm{TA}_{\mathrm{i}, \mathrm{t}}=\mathrm{a}_{0}+\mathrm{a}_{1}\left[1 / \operatorname{ASSETS}_{\mathrm{i}, \mathrm{t}-1}\right]+\mathrm{a}_{2} \Delta \operatorname{SALES}_{\mathrm{i}, \mathrm{t}}+\mathrm{a}_{3} \mathrm{PPE}_{\mathrm{i}, \mathrm{t}}+\mathrm{a}_{4} \mathrm{ROA}_{\mathrm{i}, \mathrm{t}(\mathrm{or} \mathrm{i}, \mathrm{t}-1)}+\varepsilon_{\mathrm{i}, \mathrm{t}}
$$

$\mathrm{TA}_{\mathrm{i}, \mathrm{t}}$

$\triangle$ SALES $_{i, t} \quad:$ Changes in the company's current sales value with the previous year

$\mathrm{PPE}_{\mathrm{i}, \mathrm{t}} \quad$ : The net value of the company's total fixed assets in year $\mathrm{t}$

$\mathrm{ROA}_{\mathrm{i}, \mathrm{t}}$ or $\mathrm{i,t-1}$ : Performance measurement derived from the rate of return on assets

ASSETS $_{\mathrm{i}, \mathrm{t}-1}$ : Total assets of the company in the previous year

The calculation of each variable to obtain a residual value as a measure of the quality of financial statements is as follows:

$\mathrm{TA}_{\mathrm{i}, \mathrm{t}} \quad$ : Net Income - Cash flow From Operation

$\triangle$ SALES $_{\mathrm{i}, \mathrm{t}}:$ Sales $_{\mathrm{t}-1}-$ Sales $_{\mathrm{t}}$

$\mathrm{ROA}_{\mathrm{i}, \mathrm{t}} \quad$ : Net Income/Total Assets

$\mathrm{PPE}_{\mathrm{i}, \mathrm{t}} \quad$ : Cost of Fixed Assets - Depreciation of Fixed Assets

All variables above will be divided by ASSETS $_{\mathrm{i}, \mathrm{t}-1}$ to prevent heteroscedasticity on the residual value to be obtained (Kothari et al., 2005). Thus, the calculation to obtain the residual value is as follows:

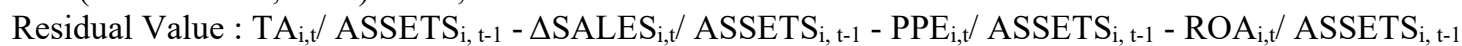
The residual value obtained will be absolute so that the discretionary accrual value will be obtained as a measurement of the variable quality of financial statements (Dechow \& Dichev, 2002).

In general, bid-ask spreads are used as a tool to measure the level of information asymmetry explicitly (Leuz \& Verrecchia, 2000). This is because bid-ask spreads are able to show adverse selection problems that arise from information asymmetry between company management and investors. Low information asymmetry will have an impact on low adverse selection and low bid-ask spreads. The bid-ask spread calculation as a measurement of the asymmetry variable is as follows (Howe \& Lin, 1992):

Information:

$$
\mathrm{SP}_{\mathrm{i}, \mathrm{t}}:\left(\mathrm{APi}_{\mathrm{t}, \mathrm{t}}-\mathrm{BP}_{\mathrm{i}, \mathrm{t}}\right) /\left(\left(\mathrm{APi}_{\mathrm{t}, \mathrm{t}}-\mathrm{BP}_{\mathrm{i}, \mathrm{t}}\right) / 2\right)
$$

$\mathrm{SP}_{\mathrm{i}, \mathrm{t}} \quad$ : Spread from company i that occurred at the t-time

$\mathrm{APi}_{, \mathrm{t}} \quad$ : The highest asking price of company i shares at the $\mathrm{t}$-time

$\mathrm{BP}_{\mathrm{i}, \mathrm{t}} \quad$ : The lowest offering price of company $\mathrm{i}$ stock at the t-time

\section{Result of Statistical Analysis}

4.1 Moderated Regression Analysis

\begin{tabular}{|c|c|c|c|c|c|c|}
\hline \multirow{2}{*}{\multicolumn{2}{|c|}{ Model }} & \multicolumn{2}{|c|}{$\begin{array}{l}\text { Unstandardized } \\
\text { Coefficients }\end{array}$} & \multirow{2}{*}{$\begin{array}{c}\begin{array}{c}\text { Standardized } \\
\text { Coefficients }\end{array} \\
\text { Beta }\end{array}$} & \multirow[b]{2}{*}{$\mathrm{t}$} & \multirow[b]{2}{*}{ Sig. } \\
\hline & & $\mathrm{B}$ & Std. Error & & & \\
\hline \multirow[t]{4}{*}{1} & (Constant) & 1.247 & 0.249 & & 4.997 & 0.000 \\
\hline & $\begin{array}{l}\text { Quality of Financial } \\
\text { Statement }\end{array}$ & -0.893 & 0.320 & -0.760 & -2.793 & 0.007 \\
\hline & Investment Efficiency & -1.050 & 0.399 & -1.193 & -2.635 & 0.010 \\
\hline & Interaction & 1.239 & 0.509 & 1.227 & 2.434 & 0.017 \\
\hline
\end{tabular}

Table 3. Moderated Regression Analysis

Based on the results of the moderated regression analysis data processing in Table 8 , the moderated regression analysis equation in this study, namely:

$$
\mathrm{Y}=1,247-0,893 \mathrm{X}_{1}-1,050 \mathrm{X}_{2}+1,239 \mathrm{X}_{1} \mathrm{X}_{2}+\mathrm{e}
$$

Based on the moderated regression analysis equation above, it can be explained that the first hypothesis states that the quality of financial statements has a negative influence on information asymmetry. The test results show the quality of financial statements using the measurement of total accruals has a regression coefficient of -0.889 with a probability of 0.007 . This means that if other variables are considered constant or zero, then every 1 percent increase in the quality of financial statements will result in a decrease in information asymmetry by 0.893 percent. The value of the significance level of 0.007 is less than 0.05 , so $\mathrm{H}_{1}$ is accepted. This shows the quality of financial statements has a negative effect on information asymmetry.

The second hypothesis states that investment efficiency moderates positively or strengthens the effect of the quality of financial statements on information asymmetry. The test results show that the product of the quality of financial statements with investment efficiency has an interaction coefficient of 1.239 with a probability of 0.017 . 
This means that the magnitude of the effect of the interaction between the quality of financial statements and investment efficiency has increased as seen from the probability value of 0.017 . While the direction of the interaction does not decrease information asymmetry, but increases information asymmetry as seen from the interaction coefficient value of 1.239. The value of the significance level of 0.017 is less than the significance level of 5 percent, then $\mathrm{H} 1$ is accepted. This shows the efficiency of investment strengthens the influence of the quality of financial statements on information asymmetry.

\section{Discussion}

5.1 The Effect of the Quality of Financial Statements on Information Asymmetry

The results of testing the first hypothesis explains that the quality of a company's financial statements negatively affects information asymmetry so that the first hypothesis (H1) of this study is accepted. This means that the higher the quality of a financial statement, the lower the information asymmetry. According to Gomariz \& Ballesta (2013), the high quality of financial statements can enable better supervision or monitoring of shareholders so that company management becomes more responsible in presenting a financial report. If company management presents quality financial reports, investors will get information based on financial statements that present the actual condition of the company so that the level of information asymmetry between the two parties will be lower and investors will be able to carry out their investment activities efficiently and optimally.

The results of the study are consistent with the results of the research of Setiany \& Wulandari (2015) which shows the quality of financial statements has a negative influence on information asymmetry. According to Cohen (2003), the presentation of quality financial information is expected to reduce information asymmetry between company management and investors. This means that the high quality of a financial statement can minimize the level of information asymmetry between company management and investors. Research by Fanani (2009) also shows the same results, namely the presentation of higher quality financial statements can reduce information asymmetry.

\subsection{Investment Efficiency Strengthens the Effect of Financial Statement Quality on Information Asymmetry}

The results of the second hypothesis test show that investment efficiency strengthens the effect of the quality of financial statements on information asymmetry. Financial statements presented in high quality by company management can minimize information asymmetry, adverse selection, and moral hazard. Investment efficiency made by internal company in developing company investment value is expected to increase the presentation of higher quality financial statements by the company management. That is because the fixed assets investment made by the company's management will reach efficiency if the information in the financial statements has described the financial position and the actual condition of the company. Presentation of quality financial statements by internal companies will affect the level of information asymmetry that is increasingly lower for the company's management with investors as seen from the level of spread. High spreads reflect high information asymmetry while low spreads reflect low information asymmetry. Investors are expected to be able to carry out their investment activities optimally based on accounting information in the financial statements that have been presented by a company.

The results of the study are consistent with the results of research by Tao Ma (2012) which states that a company should present financial reports about quality accounting information so that the company can facilitate optimal investment activities to be carried out by internal companies and affect the level of information asymmetry between the company management and investors. Bushman \& Smith's research (2003) also explains that quality financial reports can directly make company management more accountable so as to reduce information asymmetry and reduce the level of moral hazard in determining investment opportunities.

\section{Conclusions and Suggestions}

Based on the results and discussion of data processing analysis through the SPSS version 13.0 for Windows program that has been outlined in the previous section, the research conclusions namely the quality of financial statements have a negative effect on information asymmetry. Investment efficiency is able to strengthen the negative influence between the quality of financial statements on information asymmetry.

Suggestions that can be given based on the conclusions of the study are to add a number of other independent variables or find the right independent variable in the study because the coefficient of determination (R2) is relatively small at 10.2 percent indicating only 10.2 percent of the variation of the dependent variable used in research that can be explained by the independent variables. Future studies are suggested to use a wider range of samples so that future studies can provide more precise and accurate results so that they can be used more broadly and can provide more valuable benefits to many readers.

\section{References}

Amrullah, Zidni \& Fatima, Elza. 2015. Pengaruh Kualitas Laporan Keuangan dan Debt Maturity Terhadap 
Efisiensi Investasi Perusahaan di Indonesia. Skripsi Fakultas Ekonomi dan Bisnis Universitas Indonesia.

Beatty, A., Liao, S., \& Weber, J. 2009. Financial Reporting Quality, Private Information, Monitoring and the Lease-Versus-Buy Decision. Working Paper Ohio State University.

Biddle, G.C., \& Hilary, G. 2006. Accounting Quality and Firm-Level Capital Investment. The Accounting Review, 81, pp:963-982.

Biddle, G.C., Hilary, G., \& Verdi, R.S. 2009. How Does Financial Reporting Quality Relate to Investment Efficiency? Journal of Accounting and Economics, 48, pp:112-131.

Bushman, R. M., \& Smith, A. J. 2003. Transparency, Financial Accounting Information, and Corporate Governance. Financial Accounting Information and Corporate Governance. Economic Policy Review, 9(1), pp:65-87.

Bushman, R.M., Piotroski, J.D., \& Smith, A.J. 2010. Capital Allocation and Timely Accounting Recognition of Economic Losses. Journal of Business Finance \& Accounting, 38(1-2), pp:1-33.

Butar, Sansaloni Butar. 2015. Dampak Kualitas Laporan Keuangan, Regulasi Pengendalian Internal, dan Keterbatasan Keuangan Terhadap Inefisiensi Investasi. Jurnal Akuntansi dan Keuangan, 17(1), pp:57-70.

Cohen, Daniel A. 2003. Quality of Financial Reporting Choice: Determinants an Economic Consequences. http://papers.ssrn.com. Diunduh tanggal 2 Juni 2016.

Dechow, P. \& Dichev, I., 2002. The Quality of Accruals and Earnings: The Role of Accrual Estimation Errors. The Accounting Review, 77, pp:35-59.

Fanani, Zaenal. 2009. Kualitas Pelaporan Keuangan: Berbagai Faktor Penentu dan Konsekuensi Ekonomis. Jurnal Akuntansi dan Keuangan Indonesia, 6(1), pp:20-45.

Gomariz, M. Fuensanta Cutillas \& Ballesta, Juan Pedro Sanchez., 2013. Financial Reporting Quality, Debt Maturity and Investment Efficiency. Journal of Banking \& Finance, 40, pp:494-506.

Hendriksen E.S \& M.F. Van Breda. 2001. Accounting Theory, Edisi 5. McGraw-Hill. New York.

Howe, J \& Lin, Ji-Chai. 1992. Dividend Policy and The Bid-Ask Spread: An Empirical Analysis. Journal of Financial Research, 15, pp:1-10.

Indriani, Riri \& Khoiriyah, Wahiddatul. 2010. Pengaruh Kualitas Laporan Keuangan Terhadap Informasi Asimetri. Simposium Nasional Akuntansi XIII Purwokerto 2010. Universitas Jendral Soedirman Purwokerto.

Ivan Priyakusuma. 2013. Pengaruh Kualitas Laporan Keuangan terhadap Efisiensi Investasi Perusahaan. Skripsi. Fakultas Ekonomi Universitas Indonesia.

Jensen, M.C., \& W.H. Meckling. 1976. Theory of The Firm: Managerial Behaviour, Agency Cost and Ownership Structure. Journal of Financial Economics, 3(4), pp: 305-360.

Kementerian Energi dan Sumber Daya Mineral. Peraturan Menteri No. 11 Tahun 2012 Tentang Perubahan Atas Peraturan Menteri No. 7 Tahun 2012. http:/www.esdm.go.id. Diunduh tanggal 26 Mei 2016.

Kothari, S.P., Leone, A.J., \& Wasley, C.E. 2005. Performance Matched Discretionary Accrual Measures. Journal of Accounting and Economics, 39, pp:163-197.

Kusuma Tifany, Agusti Restu \& Azhar Al. 2014. Pengaruh Kualitas Pelaporan Keuangan, Kepemilikan Institusional dan Ukuran Perusahaan Terhadap Asimetri Informasi pada Perusahaan Perbankan yang Terdaftar di BEI Tahun 2008-2012. Jurnal Online Mahasiswa (JOM) Bidang Ilmu Ekonomi, 1(1), pp:1-15.

Leuz, C., \& Verrecchia, R. E. 2000. The Economic Consequences of Increased Disclosure. Journal of accounting research, 38 (Supplement), pp:91-124.

Lingmin, Xie. 2013. How Does Asymmetric Information Relate to Investment Efficiency? Evidence from Analysts' Earnings Forecasts and Daily Stock Trading. http:commons.ln.edu.hk. Diunduh tanggal 4 Juni 2016.

Ma, Tao. 2012. Financial Reporting Quality and Information Asymmetry: Evidence from the Chinese Stock Market. https://researchgate.com. Diunduh tanggal 3 Juni 2016.

Nurcholisah, Kania. 2016. The Effect of Financial Reporting Quality on Information Asymmetry and Its Impacts on Efficiency Investment. International Journal of Economics, Commerce and Management, IV(5), pp:838850.

Rahmawati, Annisa Dwi \& Harto, Puji. 2014. Analisis Pengaruh Kualitas Pelaporan Keuangan dan Maturitas Utang Terhadap Efisiensi Investasi. Diponegoro Journal of Accounting, 3(3), pp:1-12.

Sakti, Alisya Misitama. 2015. Pengaruh Kualitas Pelaporan Keuangan dan Jatuh Tempo Utang Terhadap Efisiensi Investasi. Skripsi. Fakultas Ekonomi dan Bisnis Universitas Diponegoro.

Santoso, Ari Budi. 2012. Pengaruh Kualitas Pelaporan Keuangan Terhadap Asimetri Informasi dengan Ukuran Perusahaan Sebagai Pemoderasi pada Perusahaan Manufaktur di BEI. Jurnal Ilmiah Mahasiswa Akuntansi Universitas Katolik Widya Mandala Surabaya, 1(4), pp:32-37.

Sari, Luh Indah Novita \& Suaryana,I.G.N. Agung. 2014. Pengaruh Kualitas Laporan Keuangan pada Efisiensi Investasi Perusahaan Pertambangan. Jurnal Akuntansi Universitas Udayana, 8(3), pp:524-537.

Setiany, Erna \& Wulandari, Ayu. 2015. Kualitas Pelaporan Keuangan dan Asimetri Informasi di Industri Manufaktur Indonesia. Jurnal Bisnis dan Ekonomi, 6(2), pp:17-24.

Setyawati, Lucia Jeni. 2015. Kualitas Informasi Pelaporan Keuangan: Faktor-faktor Penentu dan Pengaruhnya 
Terhadap Efisiensi Investasi. Jurnal Ekonomi dan Bisnis Airlangga, XXV, 2 Agustus 2015, pp:186-196.

Verdi, R.S. 2006. Financial Reporting Quality and Investment Efficiency. Working Paper. http://ssrn.com. Diunduh tanggal 15 Mei 2016.

Wang, Fusheng, Zhu, Zhibiao, \& Hoffmire, John. 2015. Financial Reporting Quality, Free Cash Flow, Investment Efficiency. http://www.shs-conferences.org. Diunduh tanggal 3 Juni 2016.

Arai, T., Aiyama, Y., Sugi, M. \& Ota, J. (2001), "Holonic Assembly System with Plug and Produce", Computers in Industry 46, Elsevier, 289-299.

Bell, G.A., Cooper, M.A., Kennedy, M. \& Warwick, J. (2000), "The Development of the Holon Planning and Costing Framework for Higher Education Management”, Technical Report, SBU-CISM-11-00, South Bank University, 103 Borough Road, London, SE1 0AA.

Bongaerts, L. (1998), "Integration of Scheduling and Control in Holonic Manufacturing Systems", PhD Thesis, PMA Division, K.U.Leuven.

Deen, S.M. (1993), "Cooperation Issues in Holonic Manufacturing Systems", Proceedings of DIISM'93 Conference, 410-412.

Techawiboonwong, A., Yenradeea, P. \& Das, S. (2006). A Master Scheduling Model with Skilled and Unskilled Temporary Workers", Production Economics 103, Elsevier, 798-809.

Valckenaers, P., Van Brussel, H., Bongaerts, L. \& Wyns, J. (1997), "Holonic Manufacturing Systems", Integrated Computer Aided Engineering 4(3), 191-201.

Van Brussel, H., Wyns, J., Valckenaers, P., Bongaerts, L. \& Peters, P. (1998), "Reference Architecture for Holonic Manufacturing Systems: PROSA", Computers in Industry 37(3), 255-274. 